\title{
PROCEDURES FOR GETTING PATENT RIGHTS IN TECHNOLOGY
}

\author{
Niko saputra \\ 155100054 \\ Fakultas Komputer, 448757190 \\ nikosaputra.student@umitra.ac.id
}

\begin{abstract}
Patent rights are actions that are exclusive rights of patent holders, namely regarding sales, uses and other matters relating to objects that have been patented3. In the process of obtaining a patent it has steps, as well as conditions in it, which must be fulfilled to be able to patent an invention. The requirements for inventions that can be granted patents are: new inventions, if the invention submitted by the patent is not the same as the technology revealed previously and the Invention contains an innovative step, if the invention is an unexpected thing for someone who has certain expertise in engineering, The invention can be applied in industry, meaning that inventions that can be patented are inventions that can be used in the field of industry, and contain inventive steps (renewal) and To patent a product it is not easy to pass through the procedures that have been set.
\end{abstract}

Keywords: procedure for making a patent

\section{A. INTRODUCTION}

\section{Patent definition}

Patents are the exclusive rights of inventors to inventions in the field of technology for a certain period of time implementing themselves or giving approval to other parties to carry out their inventions

\section{2. invention}

Invention is an inventor's idea that is poured into a specific problem solving activity in the field of technology, can be a product or process or a product or process improvement and development. 


\section{Inventions that can be patented}

The invention can be patented if the invention:

- If at the time of filing the application the Patent of the invention is not the same as the technology disclosed previously;

- Contains inventive steps. If the invention is an unpredictable thing for someone who has certain expertise in the field of engineering;

- Can be applied in industry. If the invention can be produced or can be used in various types of industries.

\section{How long does the Patent apply?}

- Patents are granted for a period of 20

years from the date of receipt of a patent application.

Simple patents are given for a period of

10 years from the date of receipt of a simple Patent application.

\section{How do I apply for a Patent?}

1. Submitting an application to the Office of the Directorate General of Intellectual Property (DJKI) in writing in Indonesian by filling in the application form provided and typed in duplicate

2. The applicant must attach: a. special power of attorney, if the application is submitted through a KI consultant registered as a proxy;

b. letter of transfer of rights, if the application is submitted by another party that is not inventor

c. the description of the Patent application is made in duplicate and includes:

the title of the invention, made in capital letters and not underlined;

the field of invention engineering, contains in general where the invention is included in the field of engineering by expressing its specificity;

the background of the invention, it must be stated that the technology is already in existence and relevant to the invention;

summary of the invention, contains technical characteristics of the subject matter of the invention disclosed in the claim;

a brief description of the image (if a picture is included), contains brief description of the image;

a complete description of the invention, is a disclosure of the invention as complete as possible, there must be nothing left behind or not disclosed;

claims (made on a separate page), contain the subject of the invention and may not contain images or graphics but can contain tables of mathematical formulas or chemical reactions; 
abstracts (made on a separate page), containing a summary of the complete description of the invention and no more than 200 words.

o picture, if any is made in duplicate 2: only contains signs, symbols, letters, numbers, charts, or diagrams that explain parts of the invention, but there cannot be explanatory words;

o proof of original priority, and translation of front pages in Indonesian in duplicate 2 , if submitted with priority rights;

o translation of the description of the invention in English, if the invention is originally in a foreign language other than English;

o proof of payment for Patent application fees;

3. Descriptions, claims, abstracts and images as referred to in item 2 letter c and $\mathrm{d}$ are determined as follows:

4. each sheet of paper is only one of its faces which may be used for writing and drawing;

5. descriptions, claims and abstracts are typed in HVS paper or similar and separate, A4 size, minimum weight 80 grams with the following limits:

o upper limit: $2 \mathrm{~cm}$

o lower limit: $2 \mathrm{~cm}$

o left border: $2.5 \mathrm{~cm}$

o right border: $2 \mathrm{~cm}$
6. The A4 paper must be white, flat, not glossy and its use is done by placing the short side at the top and bottom (unless used for pictures);

7. each description sheet, claim and image are numbered in Arabic numerals in the upper middle part and not in the limit as referred to in item 3 letter b (1);

8. in each of the five lines typing the description and claims, it must be given a line number and each new page is the beginning (beginning) of the number and placed to the left of the description or claim and not to the limit as referred to in item 3 letter b (3);

9. typing must be done using black ink (toner), with spacing 1.5 and upright letters with a minimum letter height of $0.21 \mathrm{~cm}$;

10. signs with lines, chemical formulas, and certain signs can be written by hand;

11. The image must use black Chinese ink on A4-size white drawing paper with a minimum weight of 100 grams which is not glossy with the following limits:

o upper limit: $2.5 \mathrm{~cm}$

o lower limit: $1 \mathrm{~cm}$

o left border: $2.5 \mathrm{~cm}$

o right border: $1.5 \mathrm{~cm}$

12. all submitted Patent documents must be in whole sheets of paper, may not be torn, folded, damaged or affixed to the image; 
13. each term used in the description, claim, abstract and image must be consistent with each other.

\section{B. CONCLUSION}

1. A patent is a special right given by someone or his request to that person who creates a new product.

2. In general there are several procedures for obtaining a patent:

Declaration of rights, transfer of rights, power of attorney, Photocopy of KTP / identigas applicant,

Photocopy of Deed of Establishment of Legalized Legal Entity,

Photocopy of NPWP for legal entities,

Photocopy of ID card in the name of the legal entity applicant to sign a statement and power of attorney,

3. Application of patents and term: Patents are given for a period of 20 years from the date of receipt of a Patent application. A simple patent is granted for a period of 10 years from the date of receipt of a simple Patent application.

4. Invention is an inventor's idea that is poured into a specific problem solving activity in the field of technology, can be a product or process or a product or process improvement and development.

5. So to take care of the patent application it is not easy to go through the stages as above and if it has been patented then the product that we make is protected by a legal entity if someone claims a patent on our product will be exposed to the article already apply.

\section{ACKNOWLEDGEMENT University Of Indonesia University Of Mitra Indonesia Telkom University University Of Mellbourne Saitama University}

\section{REFERENCE(Based ISO 690 )}

A. S. Putra And O. M. Febriani, "Knowledge Management Online Application In Pdam Lampung Province," In Prosiding International Conference On Information Technology And Business (Icitb), 2018, Pp. 181187.

[2] A. S. Putra, O. M. Febriani, And B. Bachry, "Implementasi Genetic Fuzzy System Untuk Mengidentifikasi Hasil Curian Kendaraan Bermotor Di Polda Lampung," J. Sist. Inf. Dan Manaj. Basis Data, Vol. 1, No. 1, Pp. 21-30, 2018.

[3] O. M. Febriani And A. S. Putra, "Sistem Informasi Monitoring Inventori Barang Pada Balai Riset 
Standardisasi Industri Bandar Lampung," J. Inform., Vol. 13, No. 1, Pp. 90-98, 2014.

[4] Putra, Arie Setya. "2018 Artikel Struktur Data, Audit Dan Jaringan Komputer." (2018).

[5] Putra, A. S. (2018, July 17). Paperplain Fundamental Create Application With Borland Delphi 7.0 University Of Mitra Indonesia. Retrieved From Osf.Io/Pbrn9.

\section{E. REFERENCE(Based APA )}

Putra, A. S., Aryanti, D. R., \& Hartati, I. (2018, November). Metode SAW (Simple Additive Weighting) sebagai Sistem Pendukung Keputusan Guru Berprestasi (Studi Kasus: SMK Global Surya). In Prosiding Seminar Nasional Darmajaya (Vol. 1, No. 1, pp. 85-97).

Sari, D. P., Febriani, O. M., \& Putra, A. S. (2018, November). Perancangan Sistem Informasi SDM Berprestasi pada SD Global Surya. In Prosiding Seminar Nasional Darmajaya (Vol. 1, No. 1, pp. 289-294).

Putra, A. S. (2018). Paperplain: Execution Fundamental Create Application With Borland Delphi 7.0 University Of Mitra Indonesia.

Putra, A. S., Sukri, H., \& Zuhri, K. Sistem Monitoring Realtime Jaringan Irigasi Desa (JIDES) Dengan Konsep Jaringan Sensor Nirkabel. IJEIS (Indonesian Journal of Electronics and Instrumentation Systems), 8(2), 221-232.

Darmawan, A., Yuliawati, D., Marcella, O., \& Firmandala, R. (2016). Sistem Absensi dan Pelaporan Berbasis
Fingerprint dan SMS Gateway. EXPLORE, 7(1).

Febriani, O. M., Wahyuni, T., \& Yusuf, S. (2017). DESIGN OF WEBSITEBASED INFORMATION SYSTEM FOR EDOCUMENT ADMINISTRASI IN THE COMMUNITY SERVICE UNIT (A Case Study at Rajabasa District). INTERNATIONAL JOURNAL OF COMPUTERS \& TECHNOLOGY, 16(7), 7010-7020.

Febriani, O. M., \& Wahyuni, T. (2017, October). PERANCANGAN SISTEM EDOCUMENT ADMINISTRASI LOGBOOK PENELITIAN PADA UNIT LAYANAN DI BANDAR LAMPUNG. In Prosiding Seminar Nasional Darmajaya (Vol. 1, No. 1, pp. 187-194).

Febriani, O. M., \& Permadi, A. B. (2017). Implementasi Sistem Aplikasi Data Bimbingan dan Pelanggaran Siswa pada Sekolah Menengah Atas di Lampung Tengah dengan Metode Analisis dan Desain Sistem Terdistribusi (SSAD). EXPERT, 7(1).

Febriani, O. M., \& Ambarwati, L. (2015). PERANCANGAN APLIKASI PENGOLAHAN DATA PENJUALAN UKM KELANTING KHAS TELO DESA SIDOHARJO KECAMATAN JATI AGUNG KABUPATEN LAMPUNG SELATAN. Jurnal Teknologi Informasi dan Bisnis Pengabdian Masyarakat Darmajaya, 1(1), 77-95.

Febriani, O. M. (2015). Rancang Bangun Aplikasi E-commercemenggunakan Freewebstore pada UKM Kelanting di Desa Sidoharjo Lampung Selatan. 
$\sum^{*^{*} *} \begin{aligned} & \text { Fakultas Komputer } \\ & \text { Section Class Conten }\end{aligned}$

Niko saputra

Prosiding Sembistek 2014, 1(02), 446458. 